\title{
Sistem Informasi Kepegawaian Rumah Sakit Universitas Riau Berdasarkan Standar Nasional Akreditasi Rumah Sakit (SNARS)
}

\author{
Salhazan Nasution ${ }^{1}$, Mega Bintang Purnama Sari ${ }^{2}$ \\ Program Studi Teknik Informatika, Fakultas Teknik, Universitas Riau \\ salhazan@lecturer.unri.ac.id ${ }^{1}$,mega.bintangpurnamasari@student.unri.ac.id ${ }^{2}$
}

\begin{tabular}{l}
\hline Article Info \\
\hline History : \\
Dikirim 27 Januari 2020 \\
Direvisi 07 Februari 2020 \\
Diterima 27 April 2020 \\
\hline
\end{tabular}

\section{Kata Kunci :}

Kepegawaian

Rumah Sakit

Sistem Informasi

Akreditasi

Web

\begin{abstract}
Abstrak
Rumah Sakit Universitas Riau merupakan salah satu dari 21 universitas negeri yang diamanahkan untuk mendirikan rumah sakit pendidikan yang kepemilikkannya di bawah Kementrian Pendidikan dan Kebudayaan. Bagian SDM merupakan salah satu bagian rumah sakit yang bertugas menangani administrasi pegawai. Berdasarkan hasil wawancara, bagian SDM masih melakukan pengolahan data secara manual dan kurang efisien. Kemudian tidak ada pengingat habisnya masa berlaku Surat Izin Praktek (SIP) dan Surat Tanda Registrasi (STR) bagi pegawai klinis, dimana itu akan menyusahkan karena pegawai klinis yang masa berlaku SIP dan STR-nya habis tidak diperbolehkan untuk praktek dan untuk pengurusannya sendiri membutuhkan waktu kurang lebih 6 bulan. Solusi dari masalah tersebut adalah membangun sistem informasi kepegawaian berbasis web dengan menggunakan Bahasa pemrograman PHP dan database MySQL. Sistem yang dibangun mengacu pada Standar Nasional Akreditasi Rumah Sakit (SNARS). Sistem dapat melakukan pengolahan, pencarian, penyimpanan data dan file pegawai serta pembuatan surat peringatan. Sistem juga dilengkapi dengan fitur pemberitahuan 1 tahun sebelum SIP dan STR habis masa berlaku. Pengujian sistem telah dilakukan oleh 10 orang pegawai di Rumah Sakit Universitas Riau. Dari hasil kuisioner pengujian didapatkan hasil akhir 82,66\% dengan kategori "sangat memuaskan".
\end{abstract}

(C) This work is licensed under a Creative Commons Attribution-ShareAlike 4.0 International License.

\section{Koresponden:}

Salhazan Nasution

Program Studi Teknik Informatika, Fakultas Teknik

Universitas Riau

Kampus Bina Widya Km. 12,5 Simpang Baru, Pekanbaru, Indonesia, 28293

Email : salhazan@lecturer.unri.ac.id

\section{PENDAHULUAN}

Rumah Sakit Universitas Riau merupakan salah satu dari 21 universitas negeri yang diamanahkan untuk mendirikan rumah sakit pendidikan yang kepemilikkannya di bawah Kementrian Pendidikan dan Kebudayaan. Bagian SDM merupakan salah satu bagian Rumah sakit yang bertugas menangani administrasi pegawai. Berdasarkan hasil observasi dan wawancara, bagian SDM masih melakukan pengolahan data secara manual dengan menggunakan banyak arsip atau dokumen yang berupa hardcopy serta belum memiliki suatu database khusus, sehingga 
membutuhkan waktu yang lama untuk mengelola data setiap pegawai. Kemudian tidak ada pengingat habisnya masa berlaku SIP dan STR bagi pegawai klinis, dimana itu akan menyusahkan karena pegawai klinis yang masa berlaku SIP dan STR-nya habis tidak diperbolehkan untuk praktek dan untuk pengurusannya sendiri membutuhkan waktu kurang lebih 6 bulan.

Informasi mengenai kepegawaian merupakan hal yang utama, oleh karena itu diperlukan suatu sistem yang dapat mengelola data-data pegawai sehingga memudahkan dalam menyediakan informasi dan file pegawai secara efisien. Dimana sistem tersebut dibangun dengan berdasarkan Standar Nasional Akreditasi Rumah Sakit (SNARS) sebagai acuan. Hal ini dikarenakan didalam SNARS menjelaskan tentang data-data yang dibutuhkan untuk membuat sistem kepegawaian ini dan juga agar sistem yang telah dibuat memenuhi standar akreditasi dan bisa menjadi nilai tambah saat rumah sakit akan melakukan proses pengakreditasian.

Pada penelitian terdahulu, beberapa peneliti membuat sistem informasi yang digunakan untuk kepegawaian, salah satunya oleh Aribisala dan Olusuyi yang berjudul Design of an Employee Management System (A Case Study of National iron Ore Mining Company) sistem ini memungkinkan user untuk mengelola data dan penggajjian pegawai [1]. Pada penelitian yang dilakukan oleh Karman, J dengan judul penelitian Sistem Informasi Kepegawaian Daerah pada Badan Kepegawaian, Pendidikan dan Pelatihan Kabupaten Musi Rawas Berbasis Web, sistem yang disajikan dapat menampilkan laporan berupa data pegawai berdasarkan unit kerja, klasifikasi sekolah, jabatan fungsional, usia dan jenis kelamin, jenis kelamin dan pendidikan serta berdasarkan golongan [2]. Penelitian oleh Dalke dan Deshmukh menyajikan sistem dengan dua level user yaitu staf dan kepala bagian. Pada user staff terdapat beberapa modul meliputi profil, aplikasi cuti, dashboard, dan analisis kinerja. Sedangkan modul untuk user kepala bagian meliputi profil, manajemen cuti, laporan, dashboard dan analisis kerja [3]. Kemudian penelitian yang dilakukan Abdurahman, menyajikan sistem yang dapat mengelola data pegawai pada Kementerian Kelautan dan Perikanan Kota Ternate dan mencetak laporan data pegawai [4].

\section{METODE PENELITIAN}

Penelitian ini dikembangkan dengan metode yang terdiri dari beberapa tahapan yang dapat dilihat di Gambar 1.

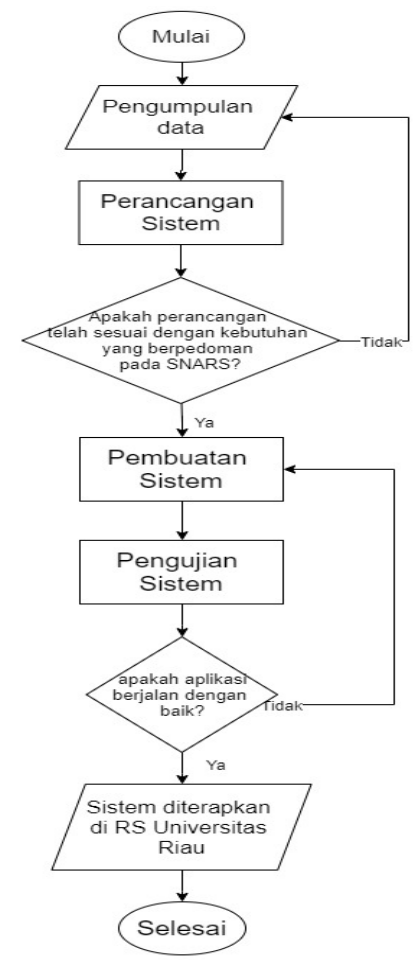

Gambar 1. Metodologi Penelitian. 


\subsection{Pengumpulan Data}

Metode pengumpulan data yang dilakukan pada penelitian ini antara lain; observasi, yakni mengamati masalah yang ada di lingkungan RS Universitas Riau yang salah satunya adalah masalah mengelola informasi serta file kepegawaian yang ada di rumah sakit. Wawancara, dilakukan dengan kepala divisi SDM yaitu Dewi S. Juwita. Dari hasil pengumpulan data didapatkan informasi bahwa dalam penyusunan laporan kepegawaian, pada praktiknya pengolahan data pegawai di Rumah Sakit Universitas Riau belum terkomputerisasi dengan baik. Bagian SDM masih melakukan pengolahan data secara manual dengan menggunakan banyak arsip atau dokumen yang berupa hardcopy serta belum memiliki suatu database khusus, sehingga membutuhkan waktu yang lama untuk mengelola data setiap pegawai. Selain itu dibutuhkan ketelitian dalam mengelola keakuratan data pegawai, karena jika sampai terjadi kesalahan maka bisa berakibat tertukarnya data antar pegawai. Gambar 2 menunjukan tempat penyimpanan data pegawai di Rumah Sakit Universitas Riau.

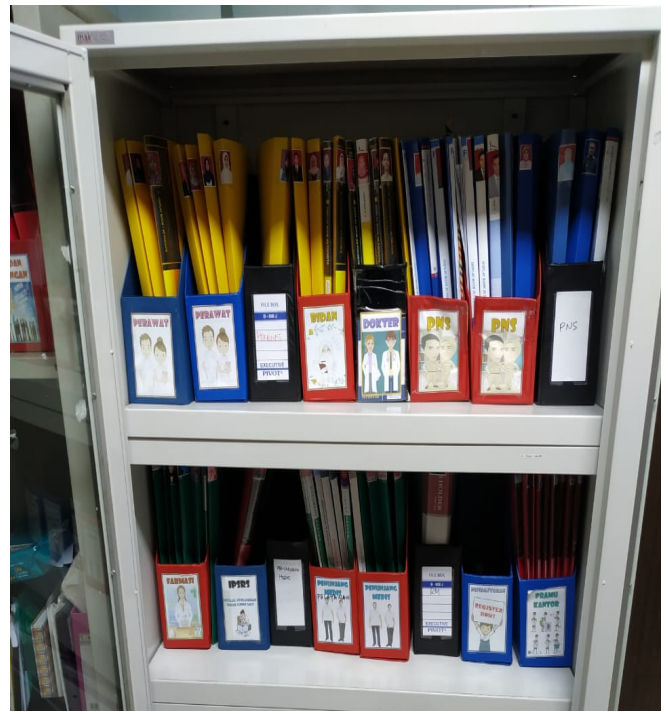

Gambar 2. Arsip Data Pegawai Rumah Sakit Universitas Riau.

\subsection{Konsep Teori}

Standar Nasional Akreditasi Rumah Sakit (SNARS) adalah acuan bagi rumah sakit untuk meningkatkan mutu pelayanan kesehatan. SNARS dikelompokkan berdasarkan fungsi-fungsi yang terkait dengan penyediaan pelayanan bagi pasien, juga dengan upaya menciptakan organisasi rumah sakit yang aman, efektif, dan terkelola dengan baik. Fungsi-fungsi tersebut tidak hanya berlaku untuk rumah sakit secara keseluruhan tetapi juga untuk setiap unit, departemen, atau layanan yang ada dalam organisasi rumah sakit tersebut. SNARS tentang kepegawaian terdapat di bab lima dengan judul Kompetensi dan Kewenangan Staff (KKS). SNARS mulai diberlakukan pada Januari 2018, berfungsi sebagai pedoman dalam mengelola organisasi rumah sakit agar efektif dan efisien, pedoman bagi pelayanan dan asuhan pasien, serta sarana untuk memahami apa saja standar yang harus dipenuhi seluruh organisasi rumah sakit dalam proses akreditasi oleh Komisi Akreditasi Rumah Sakit [5].

Sistem informasi adalah komponen terintegrasi yang mempunyai fungsi untuk mengumpulkan, menyimpan, dan memproses suatu data dalam menyediakan informasi, pengetahuan, serta produk digital. Sistem berbasis web adalah aplikasi yang berada dalam server dan dapat diakses dengan menggunakan web browser serta dapat diakses dimana saja melalui internet [6]. PHP yang merupakan singkatan dari PHP: Hypertext Preprocessing adalah bahasa pemrograman yang disebut bahasa scripting, maksudnya adalah PHP merupakan bahasa pemrograman yang dapat ditempelkan pada bahasa atau aplikasi lain. PHP merupakan bahasa pemrograman web yang paling populer saat ini dikarenakan beberapa hal antarai lain mudah dibuat

Salhazan Nasution, Sistem Informasi Kepegawaian Rumah Sakit Universitas Riau Berdasarkan Standar Nasional Akreditasi Rumah Sakit (SNARS) 
dan kecepatan akses yang tinggi, dapat berjalan di web server yang berbeda dan sistem operasi yang berbeda pula, PHP merupakan server-side programming bersifat open source, PHP termasuk kedalam Bahasa yang embedded (bisa ditempel atau diletakkan kedalam tag HTML) [7]. MySQL merupakan sebuah software database SQL yang bersifat open source yang bertujuan untuk menangani sistem manajemen database dan sistem manajemen database relasional (Relational Database Management System). Secara khusus, MySQL juga menambahkan sejumlah fungsi yang membuat perintah SQL pada MySQL menjadi sangat variatif. Tambahan-tambahan tersebut membuat keleluasaan dalam mengakses database dan melakukan berbaga tindakan lainnya [8].

Usability testing merupakan salah satu metode pengujian untuk mengetahui tingkat efisien dan efektif suatu aplikasi bagi pengguna. Pengujian usability dilakukan untuk mengetahui sebuah aplikasi sudah dapat berjalan sesuai dengan kebutuhan pengguna atau belum [9]. Usabilty testing dilakukan untuk mengetahui sejauh mana produk dapat digunakan oleh pengguna tertentu untuk mencapai tujuan yang ditentukan dengan efektifitas, efisiensi, dan kepuasan dalam konteks yang ditentukan untuk digunakan [10]. Terdapat 5 aspek pengujian usability yaitu Kemudahan (learnability), Efisien (efficiency), Mudah diingat (memorability), Kesalahan dan keamanan (errors), Kepuasan (satisfaction) [11]. Skala likert digunakan untuk mengukur sikap, pendapat, dan persepsi seseorang atau sekelompok orang tentang fenomena sosial. Dalam penelitian, fenomena sosial ini telah ditetapkan secara spesifik oleh peneliti, yang selanjutnya disebut sebagai variabel penelitian [12] . Skala likert dikembangkan pertama kali menggunakan 5 titik respon yaitu sangat setuju, setuju, tidak memutuskan atau netral, tidak setuju, dan sangat tidak setuju. Tabel 1 menunjukkan bobot skala likert dan Tabel 2 menunjukkan presentase penilaian.

Tabel 1. Bobot Skala Likert.

\begin{tabular}{cc}
\hline Kategori & Nilai \\
\hline Sangat Setuju (SS) & 5 \\
Setuju (S) & 4 \\
Netral(N) & 3 \\
Tidak Setuju (TS) & 2 \\
Sangat Tidak Setuju (STS) & 1 \\
\hline
\end{tabular}

Tabel 2. Presentase Penilaian.

\begin{tabular}{cl}
\hline Presentase Jawaban & \multicolumn{1}{c}{ Kategori } \\
\hline $0 \%-19,99 \%$ & Sangat Tidak Memuaskan \\
$20 \%-39,99 \%$ & Tidak Memuaskan \\
$40 \%-59,99 \%$ & Cukup \\
$60 \%-79,99 \%$ & Memuaskan \\
$80 \%-100 \%$ & Sangat Memuaskan \\
\hline
\end{tabular}

Pengujian usability telah dilakukan oleh beberapa peneliti sebelumnya untuk mengukur tingkat kepuasan pengguna terhadap sistem yang telah dibangun. Penelitian oleh B. Pudjoatmodjo and R. Wijaya yang melakukan usability testing pada Aplikasi Kepegawaian di Dinas Pertanian Kabupaten Bandung [13], penelitian oleh Nasution dan Frianti yang mengukur usability terhadap Sistem Informasi Inventori di Rumah Sakit Universitas Riau [14]. Tidak hanya pada sistem informasi, pengujian usability juga dapat dilakukan pada perangkat lunak lainnya [15].

\subsection{Perancangan Sistem}

Pada tahap perancangan sistem ini dibagi 3 yaitu perancangan sistem, perancangan database, dan perancangan antarmuka. Pada sistem ini terdapat 4 level pengguna yaitu Super Admin, Admin, Direktur Rumah Sakit, dan Pegawai. Dimana super admin adalah pegawai bagian IT, admin adalah pegawai bagian SDM, dan user adalah pegawai di Rumah Sakit Universitas Riau. Diagram konteks dari sistem informasi kepegawaian ini dapat dilihat pada Gambar 2. 


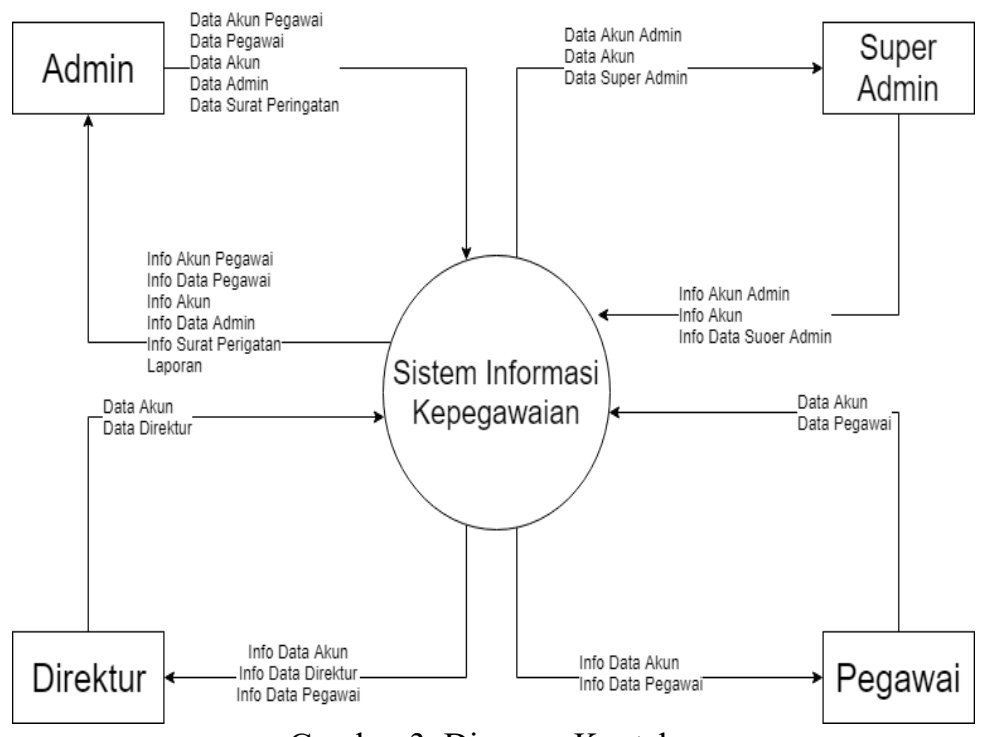

Gambar 3. Diagram Konteks.

Perancangan database dalam Sistem Kepegawaian ini berfungsi untuk menampung data-data pegawai. Database yang digunakan adalah MySQL dan memiliki 11 tabel. Relasi tabel Sistem Informasi Kepegawaian Rumah Sakit dapat dilihat pada Gambar 4 berikut ini.

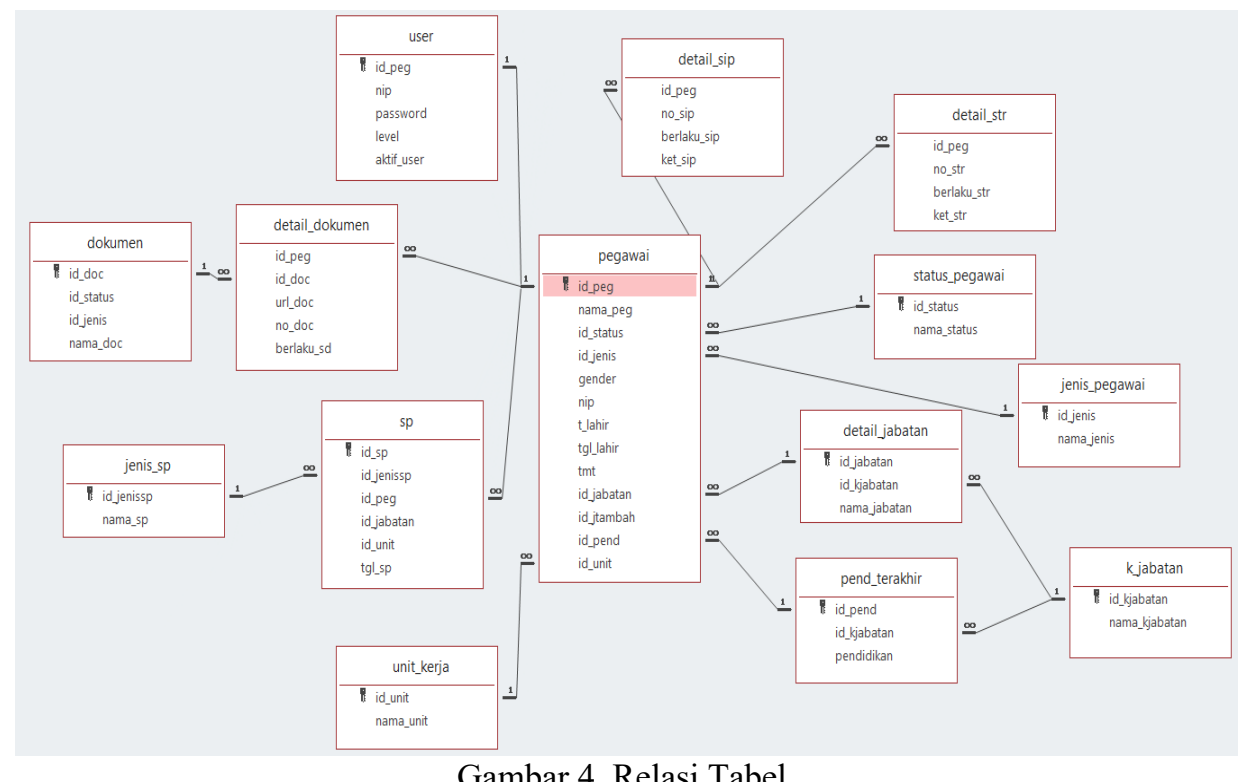

\section{HASIL DAN PEMBAHASAN}

\subsection{Implementasi Sistem}

Pada tahapan ini dilakukan implementasi kepada user yang akan menggunakan sistem ini. Sistem ini akan digunakan oleh pegawai SDM, pegawai IT, Direktur serta pegawai di Rumah Sakit Universitas Riau. Berikut adalah beberapa gambar antarmuka dari Sistem Informasi Kepegawaian Rumah Sakit Universitas Riau. Gambar 5 adalah antarmuka dari halaman utama sistem sekaligus halaman login yang akan digunakan untuk staff SDM, direktur Rumah sakit, dan pegawai untuk masuk ke sistem. Untuk masuk ke sistem user harus memasukkan NIP dan password yang sesuai. Jika berhasil login user akan langsung menuju ke halaman dashboard tergantung level user yang bersangkutan, dan jika tidak berhasil sistem akan menampilkan pesan gagal. 


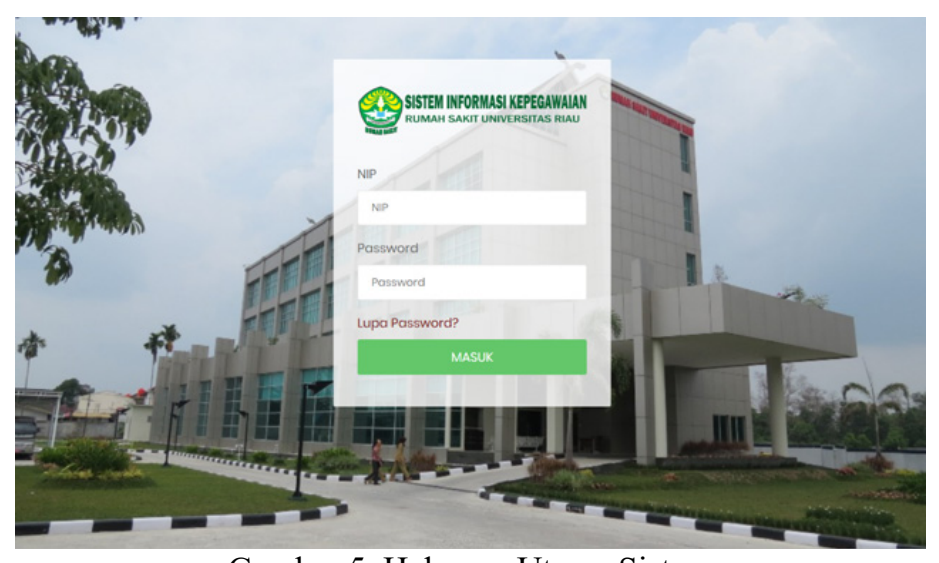

Gambar 5. Halaman Utama Sistem

Menu dashboard merupakan menu utama dari sistem untuk super admin, direktur dan pegawai. Perbedaannya hanya terdapat pada sidebar. Sidebar untuk super admin terdapat tambahan menu yakni menu pengaturan akun admin. Sementara untuk direktur terdapat tambahan menu data pegawai dan dokumen pegawai. Pada halaman dashboard user dapat melihat informasi pribadi, foto profil, serta file dokumen. Antarmuka menu dashboard dapat dilihat pada Gambar 6.

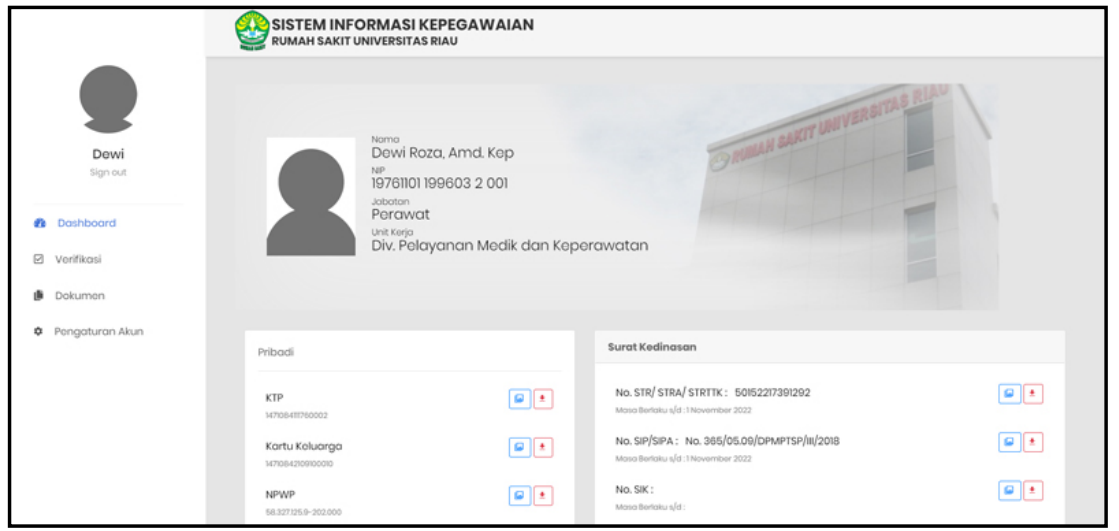

Gambar 6. Antarmuka Dashboard Super Admin.

Gambar 7 adalah antarmuka dashboard Admin SDM, yang merupakan menu utama saat user telah masuk ke sistem sebagai admin SDM. Dimana admin SDM dapat melihat total jumlah admin SDM dan pegawai, berapa banyak Surat Izin Praktek (SIP) dan Surat Tanda Registrasi (STR) yang hampir habis masa berlaku. Pada halaman ini admin SDM juga dapat melihat siapa sajakah pegawai yang SIP dan STR-nya hampir habis masa berlaku dan yang sedang dalam proses.

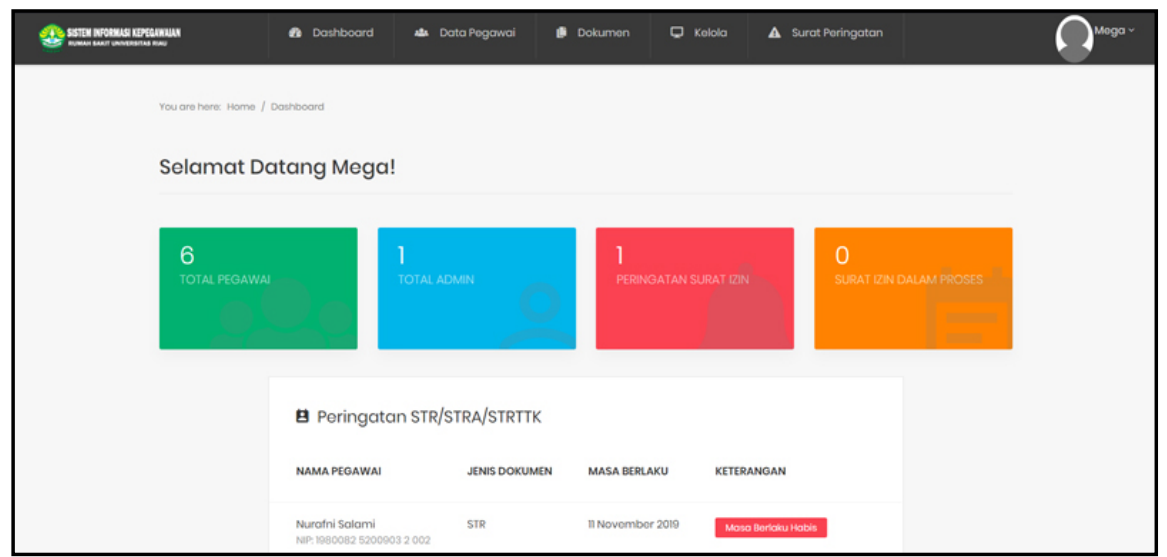

Gambar 7. Antarmuka Dashboard Admin SDM.

Salhazan Nasution, Sistem Informasi Kepegawaian Rumah Sakit Universitas Riau Berdasarkan Standar Nasional Akreditasi Rumah Sakit (SNARS) 
Antarmuka untuk menu akun pegawai berisi data akun pegawai di Rumah Sakit Universitas Riau. Pada halaman ini admin SDM dapat menambah akun pegawai, melihat nama dan username pegawai serta dapat mengubah hak akses/ status pegawai apakah pegawai tersebut masih aktif atau tidak. Antarmuka menu akun pegawai dapat dilihat pada Gambar 8.

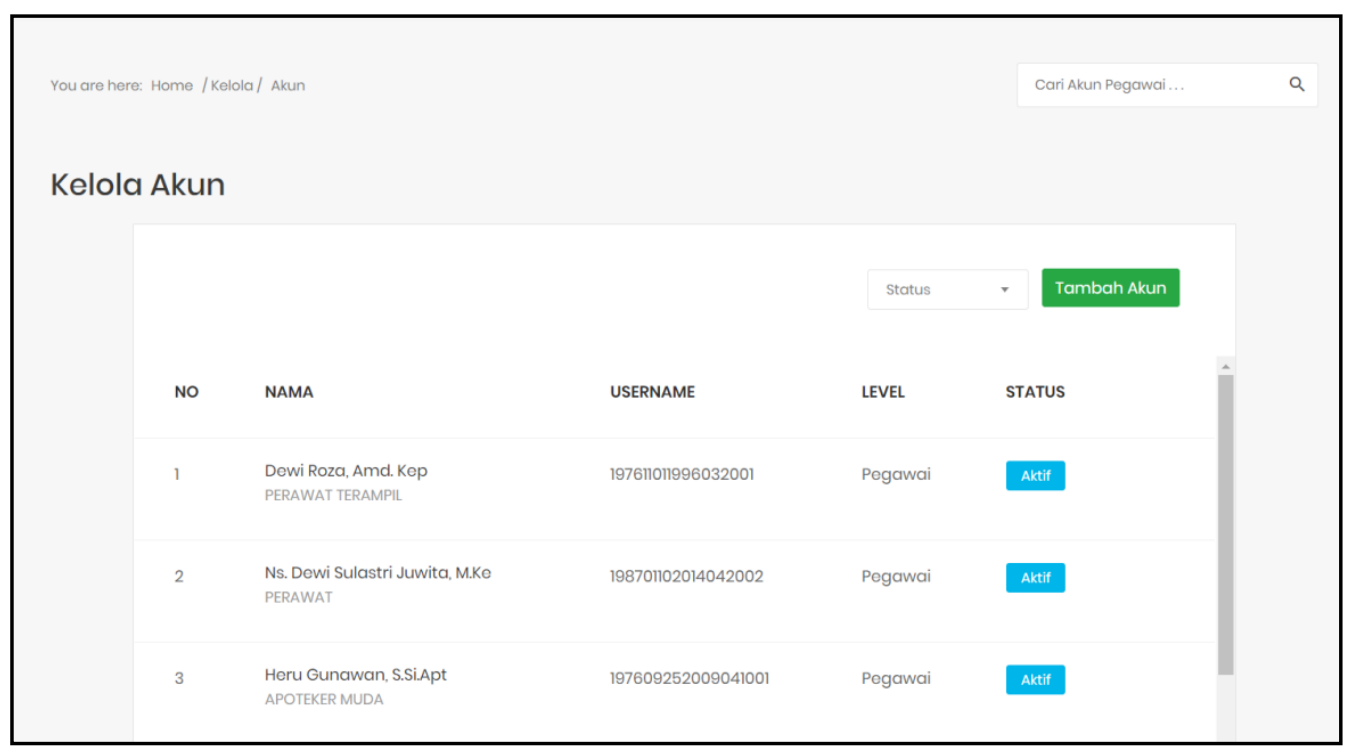

Gambar 8. Antarmuka Kelola Akun Pegawai

Antarmuka untuk menu data pegawai berisi tentang data pegawai di Rumah Sakit Universitas Riau. Di halaman ini admin SDM dapat melihat informasi mengenai pegawai di rumah sakit seperti, NIP, golongan, status pegawai dan sebagainya. Admin juga dapat membuat rekap data pegawai ke Excel serta mengunduh file dokumen pegawai untuk digunakan kembali. Antarmuka menu data pegawai dapat dilihat pada Gambar 9.

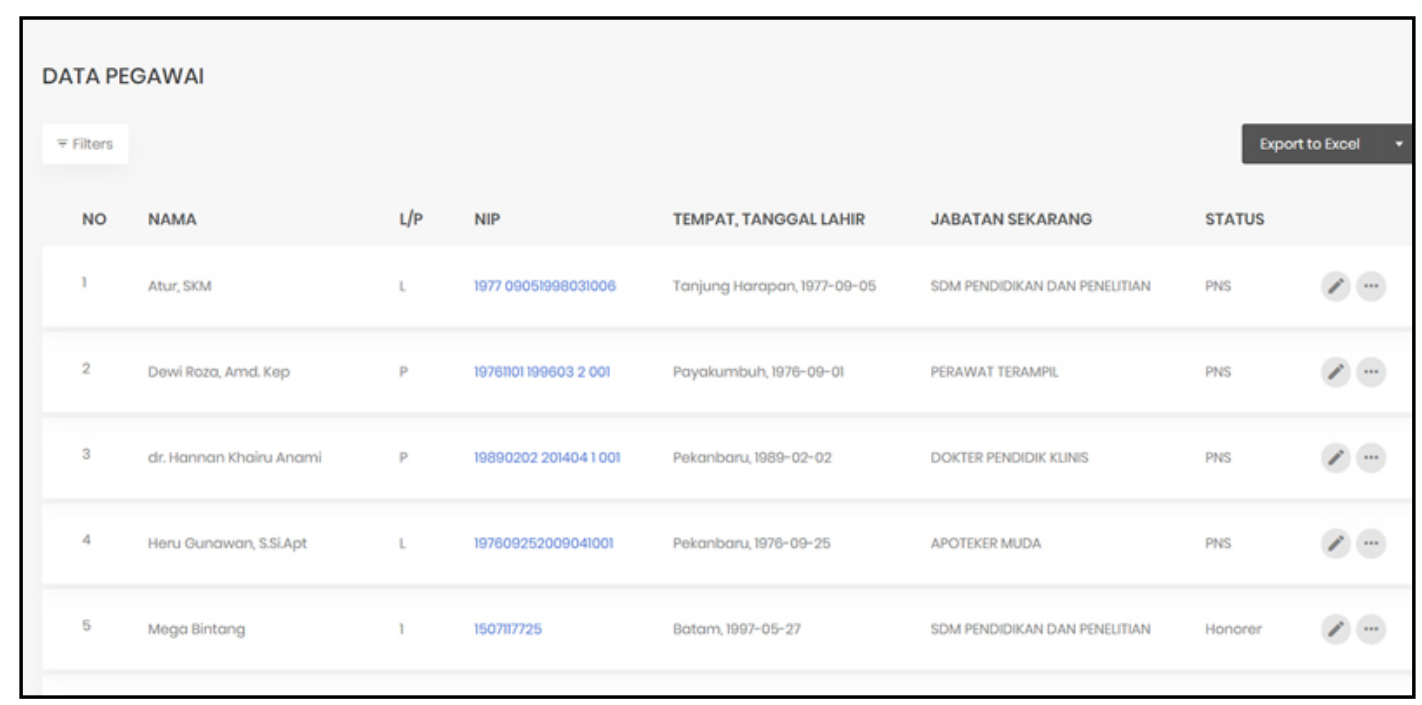

Gambar 9. Antarmuka Data Pegawai.

Antarmuka untuk menu verifikasi berisi tentang status dokumen yang telah diunggah sebelumnya. Dihalaman ini user akan diberi tahu apakah dokumen itu telah diverifikasi atau gagal dalam verifikasi. Halaman ini juga terdapat dihalaman untuk direktur serta pegawai. Antarmuka menu verifikasi dapat dilihat pada Gambar 10. 


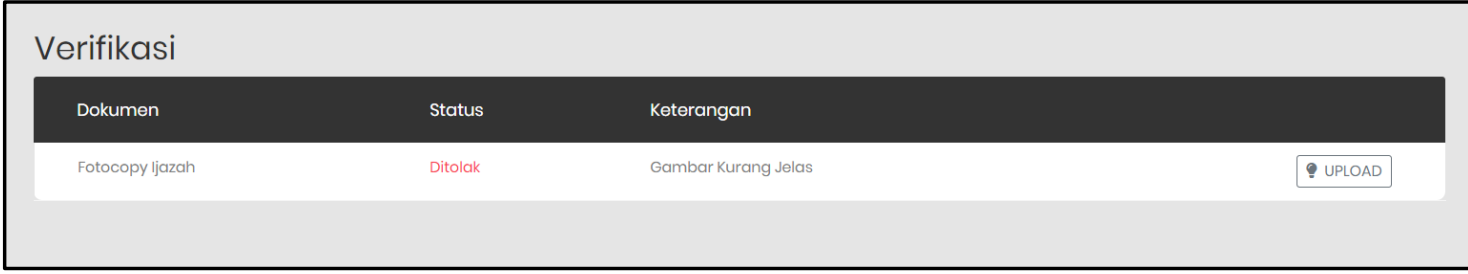

Gambar 10. Antarmuka Verifikasi Dokumen.

Antarmuka untuk menu dokumen berisi daftar file dokumen pegawai di Rumah Sakit Universitas Riau yang telah diunggah oleh pegawai. Di halaman ini direktur atau admin dapat melihat dokumen berdasarkan kategori. Kemudian juga dapat mengunduh dokumen yang ada. Rancangan tampilan menu dokumen dapat dilihat pada Gambar 11.

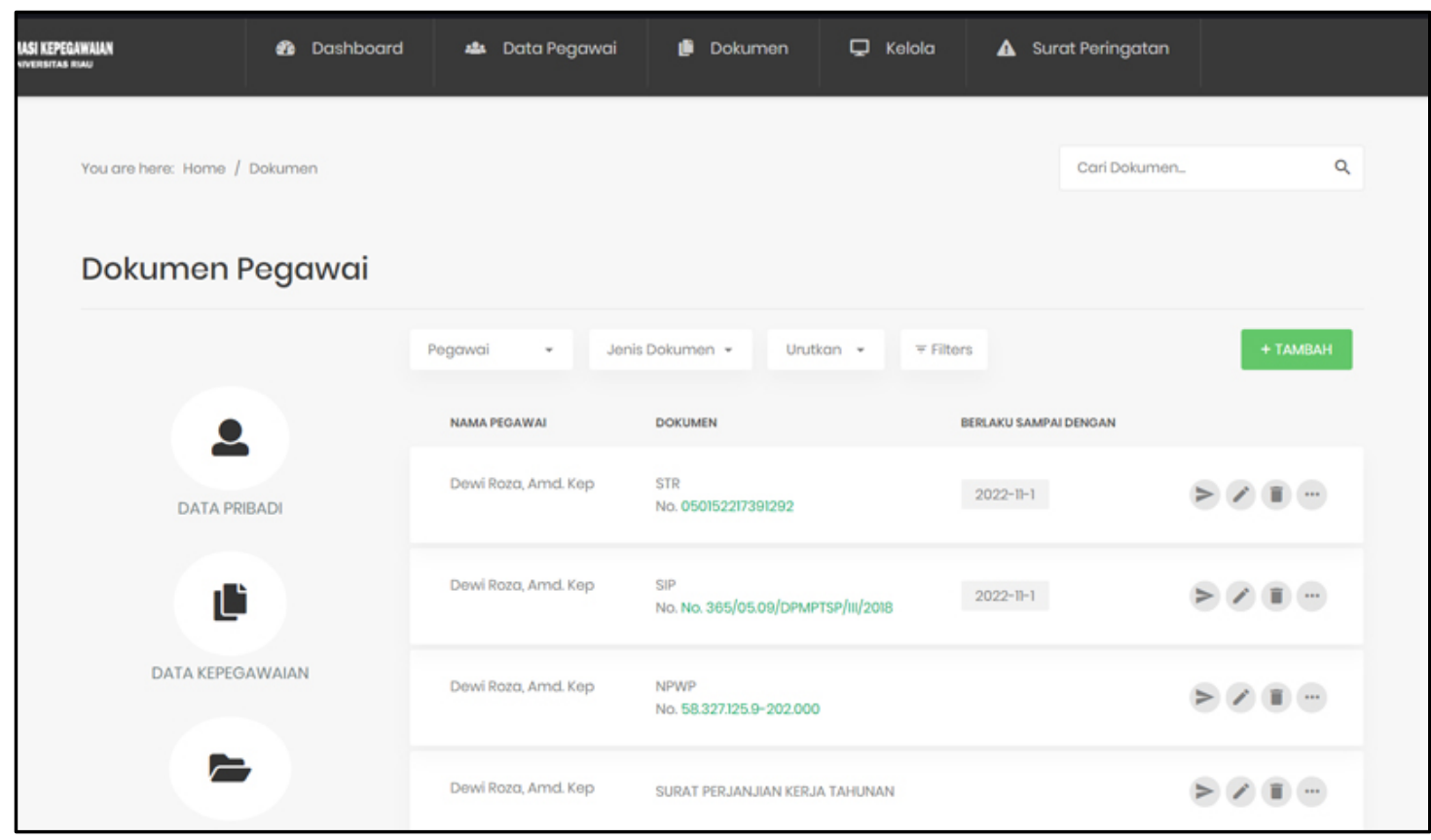

Gambar 11. Antarmuka Dokumen Pegawai.

\subsection{Uji Kelayakan Sistem}

Pengujian yang dilakukan adalah dengan menggunakan metode Usability testing yang dilakukan kepada pengguna yang akan menggunakan sistem. Usability testing merupakan salah satu metode pengujian untuk mengetahui tingkat efisien dan efektif suatu aplikasi bagi pengguna. Pada pengujian ini pengguna mencoba fungsionalitas dari sistem yang dibuat, pengujian ini dilakukan untuk mengukur tingkat kebergunaan dari sudut pandang user yang akan menggunakan sistem ini baik dari segi learnability, efficiency, memorability, errors dan satisfaction. Setelah itu pengguna diminta untuk melakukan pengisian kuesioner untuk mengukur usability sistem ini. Responden untuk penelitian ini berjumlah 10 orang yang mana merupakan pegawai Rumah Sakit Universitas Riau, dimana pegawai bagian IT sebagai super admin SDM, pegawai SDM yang bertugas sebagai admin, pegawai klinis yakni dokter dan perawat sebagai user dan pegawai nonklinis yakni staff biasa sebagai user. Hasil kuesioner dihitung menggunakan salah satu skala penilaian yakni skala Likert.

Tingkat kemudahan penggunaan sistem dari jawaban yang diberikan oleh responden dihitung dengan rumus:

$$
\text { Tingkat Kepuasan }(\%)=\frac{\text { Skor Rata-Rata }}{\text { Skor Ideal }} \times 100 \%
$$


Skor rata-rata dihitung dengan rumus:

$$
\text { Skor Rata-Rata }=\frac{\text { Total Skor }}{\text { Jumlah Pertanyaan }}
$$
tabel 1 .

Berikut adalah hasil kuesioner uji usability sesuai dengan perhitungan skala likert pada

\begin{tabular}{|c|c|c|c|c|c|c|c|c|}
\hline \multirow{2}{*}{ No } & \multirow{2}{*}{ Pertanyaan } & \multicolumn{5}{|c|}{ Jawaban } & \multirow{2}{*}{$\begin{array}{l}\text { Total } \\
\text { Skor }\end{array}$} & \multirow{2}{*}{$\begin{array}{c}\text { Persentas } \\
(\%)\end{array}$} \\
\hline & & STS & TS & $\mathrm{N}$ & $\mathrm{S}$ & SS & & \\
\hline 1 & Antarmuka sistem menarik. & & & & 8 & 2 & 42 & $84 \%$ \\
\hline 2 & $\begin{array}{l}\text { Antarmuka sistem mudah dimengerti } \\
\text { (user friendly). }\end{array}$ & & & & 7 & 3 & 43 & $86 \%$ \\
\hline 3 & $\begin{array}{l}\text { Penggunaan komposisi warna pada } \\
\text { sistem sesuai/tidak berlebihan. }\end{array}$ & & 1 & 2 & 7 & & 36 & $72 \%$ \\
\hline 4 & $\begin{array}{l}\text { Fitur menu sesuai dengan apa yang } \\
\text { dibutuhkan user. }\end{array}$ & & & 2 & 7 & 2 & 41 & $82 \%$ \\
\hline 5 & Teks yang ada mudah untuk dibaca. & & & & 8 & 2 & 42 & $86 \%$ \\
\hline \multirow[t]{3}{*}{6} & Alur penggunaan sistem informasi & & & & 6 & 4 & 44 & $88 \%$ \\
\hline & Total & & & & & & 248 & \\
\hline & Rata-rata & & & & & & 41,33 & $82,66 \%$ \\
\hline
\end{tabular}

Dari hasil kuesioner didapatkan hasil akhir 82,66\%. Merujuk pada Tabel 2 sebelumnya maka nilai tersebut dapat dikategorikan sangat memuaskan.

\section{KESIMPULAN}

Sistem Informasi Kepegawaian Rumah Sakit Universitas Riau dibangun berdasarkan Standar Nasional Akreditasi Rumah Sakit (SNARS) sebagai acuannya. Pada sistem ini terdapat 4 level pengguna yaitu Super Admin, Admin (staf SDM), Direktur Rumah Sakit, dan Pegawai. Sistem dapat melakukan pengolahan, pencarian, penyimpanan data dan file pegawai serta pembuatan surat peringatan. Sistem juga dilengkapi dengan fitur pemberitahuan 1 tahun sebelum SIP dan STR habis masa berlaku. Pengujian usability sistem telah dilakukan oleh 10 orang pegawai di Rumah Sakit Universitas Riau. Dari hasil kuisioner pengujian usability yang dilakukan, didapatkan hasil akhir $82,66 \%$ dengan kategori "sangat memuaskan".

\section{DAFTAR PUSTAKA}

[1] A. Aribisala and K. Olusuyi, "Design of an employee management system (a case study of National iron Ore mining company, Itakpe)," 2014.

[2] J. Karman, "Sistem Informasi Kepegawaian Daerah Pada Badan Kepegawaian, Pendidikan dan Pelatihan Kabupaten Musi Rawas Berbasis Web," J. Sisfokom (Sistem Inf. dan Komputer), vol. 6, no. 2, p. 105, Sep. 2017.

[3] S. Pramod Dalke Shruti Anil Deshmukh, J. Govind Dalave Vaishnavi Nitin Sasane, and P. K. Dhule Assistant Professor, "Web Based Staff Management System," 2017.

[4] M. Abdurahman, "Sistem Informasi Data Pegawai Berbasis Web Pada Kementerian Kelautan Dan Perikanan Kota Ternate," J. Ilm. Ilk. - Ilmu Komput. Inform., vol. 1, no. 2, pp. 70-78, 2018.

[5] K. A. R. Sakit, "Standar Nasional Akreditasi Rumah Sakit Edisi 1," Jakarta KARS, 2017.

[6] E. Turban, R. K. Rainer, and R. E. Potter, Introduction to information technology, vol. 2. John Wiley \& Sons, 2005.

[7] S. B. Sakur, "PHP 5 Pemrograman Berorientasi Objek--Konsep \& Implementasi," Salhazan Nasution, Sistem Informasi Kepegawaian Rumah Sakit Universitas Riau Berdasarkan Standar Nasional Akreditasi Rumah Sakit (SNARS) 
Yogyakarta Andi, 2010.

[8] A. Kadir, "Tuntunan Praktis Belajar Database Menggunakan MySQL," Yogyakarta. Penerbit Andi, 2008.

[9] Y. Nurhadryani, S. K. Sianturi, I. Hermadi, and H. Khotimah, "Pengujian Usability untuk Meningkatkan Antarmuka Aplikasi Mobile," J. Ilmu Komput. dan Agri-Informatika, vol. 2, no. 2, pp. 83-93, Nov. 2013.

[10] N. Asnawi, "Pengukuran Usability Aplikasi Google Classroom Sebagai E-learning Menggunakan USE Questionnaire (Studi Kasus: Prodi Sistem Informasi UNIPMA)," Res. Comput. Inf. Syst. Technol. Manag., vol. 1, no. 01, p. 17, Apr. 2018.

[11] W. Dimuksa, P. D. Abda'u, and J. Karaman, "Usability Evaluation pada Website STKIP PGRI Pacitan," SEMNASTEKNOMEDIA ONLINE, vol. 4, no. 1, pp. 115-120, Feb. 2016.

[12] Sugiyono, Metode penelitian pendidikan:(pendekatan kuantitatif, kualitatif dan $R \& D$ ). Alfabeta, 2008.

[13] B. Pudjoatmodjo and R. Wijaya, "TES KEGUNAAN (USABILTY TESTING) PADA APLIKASI KEPEGAWAIAN DENGAN MENGGUNAKAN SYSTEM USABILTY SCALE (STUDI KASUS : DINAS PERTANIAN KABUPATEN BANDUNG)."

[14] S. Nasution and R. A. Frianti, "Sistem Informasi Inventori Obat Berbasis Web di Rumah Sakit Universitas Riau," Semin. Nas. APTIKOM 2019, vol. 0, no. 0, pp. 402-409, Nov. 2019.

[15] S. Nasution, A. H. Nasution, and A. L. Hakim, "PEMBUATAN PLUGIN TILE-BASED GAME PADA UNITY3D,” IT J. Res. Dev., Aug. 2019.

\section{BIOGRAFI PENULIS}

\begin{tabular}{|l|l|}
\hline Salhazan Nasution obtained Bachelor Degree in Informatics Engineering from Universitas \\
Islam Indonesia in 2008, obtained Master Degree in Management Information System from \\
National University of Malaysia in 2015. He has been a Lecturer with the Department of \\
Informatics Engineering Universitas Riau Indonesia since 2014. His current research interests \\
include Information System and Management, Mobile Application and Usability.
\end{tabular}

Salhazan Nasution, Sistem Informasi Kepegawaian Rumah Sakit Universitas Riau Berdasarkan Standar Nasional Akreditasi Rumah Sakit (SNARS) 